\title{
Innovation habitats from University of Brasilia - case study of Macofren - Chemical Technologies startup
}

\author{
Grace Ferreira Ghesti ${ }^{0}$ Adriana Regina Martin ${ }^{b}$, Sanderson César Macêdo Barbalhoc \\ aLaboratório de Processos Cervejeiros e Catálise Ambiental, Instituto de Química, Universidade de Brasília - UnB \\ bDepartamento de Políticas de Desenvolvimento e Inovação de Tecnologias Estruturantes, Ministério da Ciência, Tecnologia, Inovação e Comunicação - MCTIC \\ 'Departamento de Engenharia de Produção, Faculdade de Tecnologia, Universidade de Braślia - UnB \\ e-mails: ghesti.grace@gmail.com; adriana.martin@matic.gov.br; sandersoncesar@unb.br
}

\begin{abstract}
The University of Brasilia, UnB, was founded on April 21, 1962, at Brasilia City on Midwest region of Brazil with the promise of reinventing higher education, interweaving the various forms of knowledge and training professionals engaged in the transformation of the country. In the Chemical Institute of UnB, it was developed an alternative methods for simple and cheaper technology to determine methanol and formaldehyde content in fuels and some other products. In this case will be presented an example of innovative technology developed at UnB and licensed for post graduate entrepreneurs students of UnB which created the Startup Macrofren - Chemical Technology that was incubated at business incubator of UnB. The startup also was supported by government funding. So, this case shows the existing innovation ecosystem in Brasilia city.
\end{abstract}

Keywords: innovation habitats, technology development, research and development, entrepreneurship, academic spin-offs.

\section{Introduction}

The University of Brasilia, UnB, here discussed was founded on April 21, 1962, at Brasilia City in Brazil's Federal District, on Midwest region of the country with the promise of reinventing higher education, interweaving the various forms of knowledge by breaking with the traditional model of university and training professionals engaged in the transformation of the country according to the Brasília's dream as a symbol of modernization of the country. In addition, it was conceived in the legal form of functioning of the university through a public foundation of private law, to guarantee greater financial autonomy and to manage sustainability in the fulfillment of its goals. A transformative university, with the mission of producing, integrating and disseminating knowledge, forming citizens committed to ethics, social responsibility, economic and social development and sustainability.

Currently UnB has about 55,000 students, 2,500 professors, about 110 undergraduate courses and 130 postgraduate courses. There are 29 faculties and institutes divided into four campus that cover the pilot plan and three satellites cities of the federal district, a region with about 3 million inhabitants and one of the highest gross domestic product, GDP, per capita in Brazil.
The proposal of UnB management model was potentially innovative because it was possible to expand funding sources through the public and private relationship and the development of research to promote innovation. This strategic vision was the starting point for creating an environment friendly to change the university until then existing in the country in order to make it entrepreneurial and innovative.

In 1986 it was created the Technological Innovation Nucleus of the UnB that is called Center for Support to Technological Development of the University of Brasília $\mathrm{CDT} / \mathrm{UnB}$ to support and expand the scientific, technological and innovation activities of UnB. The CDT/UnB officially acts as the Nucleus of Technological Innovation (NIT) of the $\mathrm{UnB}$, as provided for in the Innovation Law (10,973/2004). This designation was formalized through the Rectory Act No. 882/2007.

The CDT/UnB supports the research and development of entrepreneurship, as well as strengthening the existing links between society, business and government. The activities are based on four areas of activity: business development that encompasses the projects hotel and the business incubator; teaching, research and dissemination of entrepreneurship that includes the junior company program and the school of 
entrepreneurs; technology transfer that includes technology disk program, the brazilian technical responses service, the intellectual property nucleus and the technology commercialization agency and the management of institutional cooperation: university, company, government and society that encompasses the laboratory of technological innovations for environments of experience and project management.

This study describes a case study of MACOFREN the Chemical Technology Startup - and the performance of the $\mathrm{CDT} / \mathrm{UnB}$ as innovation habitats from $\mathrm{UnB}$. The work of CDT/UnB in this case initially covers the aspect of institutional cooperation describing the services that were initially provided by the laboratory of materials and fuels located in Chemical Institute of UnB, where the technology was developed for the companies. Subsequently, the $\mathrm{CDT} / \mathrm{UnB}$ performance regarding to the school of entrepreneurs where the founding members of the startup attended the disciplines related to entrepreneurship and innovation, besides the own programs of scientific initiation, master and doctorate that the students developed leaving the aspect of the research so common in areas such as Chemistry, through the establishment of the Macrofren startup. The startup was incubated in the business incubator of UnB where it had access to the physical structure and trainings that were qualifications necessary to maturity of the business, and finally the technology transfer aspect encompassing both, the protection of technology to solve the problem presented by companies of the Oil and Gas sector resulting from the research project developed, as the commercialization of technology.

Next section will present the theoretical basis. Follows the study methodology and after the results. The last section brings discussion and concluding remarks from this study.

\section{Theoretical reference}

The universities around the world are going through an important transition. This is due to the growing importance of scientific and technological knowledge and innovation to intensify economic and social development and the continuous transformations in the global economic context. The current challenge is to find out how to use and transfer scientific and technological knowledge generated by universities to achieve increasing benefits in the social and economic spheres (NASSIF et al., 2014).

From a historical point of view (ETZKOWITZ et al., 1995) they identified two major revolutions undergone by universities since its creation in the eleventh century in Europe, escaping from the conservatism that prioritized only the mission of transmitting the knowledge of teachers to students. The first revolution occurred in the late seventeenth century, in the United States, characterizing research as a mission of the university. The second revolution began in the second half of the twentieth century through the experiences of universities such as MIT Stanford and Harvard. At this moment a new concept of entrepreneurial university emerged and this would be directed to economic and social development, as well as teaching and research

In this context, recent years have been characterized by a rapid increase of development initiatives based in technology mainly focused on stimulating technological entrepreneurship in universities through partnerships between the company and university, technology transfer and spin-offs creation (CHESBROUGH, 2007; VAN GEENHUIZEN; SOETANTO, 2009; RASMUSSEN; MOSEY; WRIGHT, 2014). And this characterizes the already mentioned second academic revolution, which is still under way, with the rise of the university role in social and economic development and innovation in knowledge-based societies (ETZKOWITZ et al., 1995). Faced with this scenario the university is becoming more proactive in managing collaboration with the company. It is encouraging entrepreneurial thinking through disciplines related to innovation and entrepreneurship, creating business incubators and encouraging the protection of intellectual property as an active for the promotion of technology transfer (LEYDESDORFF et al., 2006).

Some other trends influence the daily activities in Universities and the whole context of innovation. First we have a hard focus of the private sector in terms of outsourcing research and development effort under the concept of open innovation (CHESBROUGH, 2007; VAN GEENHUIZEN \& SOETANTO, 2009). Many studies report the role of entrepreneurial startups as a way of reducing costs and maintain focus of the mainstream in large companies (LEYDESDORFF; IVANOVA, 2016; IVANOVA et al., 2014; GEENHUIZEN et al., 2009). Authors state a startup way as a form to bring disruptive technologies in the market, and a way to manage technology trends as spin offs from large companies (CHRISTENSEN et al., 1999). Open innovation are also reported as a way to connect universities to companies in high risky projects and collateral efforts of innovation while the companies R\&D focus on the existent products and markets (GUERRERO; URBANO, 2017; LEYDESDORFF; IVANOVA, 2016). The second trend has reveled from research of Mazucatto (MAZUCATTO, 2011) and other (RASMUSSEN; BORCH, 2010; GEENHUIZEN et al., 2009) which gathered data from innovation effort on main economies and discover a funding profile where the public sector have assumed the high risk projects in terms of funding, even when return is far in the future. These research shows efforts such as internet, autonomous vehicle, bio-technology successful companies and renewal energy endeavors fit a profile in which the State made a long term planning and seed private 
sector as the appropriate funds for develop innovative and disruptive products.

The case discussed in this study stay along these theories and intents to contribute discovering operational mechanisms by which a disruptive product can achieve market success under a dynamic environment and organizational architecture.

\section{Methodology}

The methodological approach chosen in this study is the exploratory one (YIN, 2009), since the mechanisms that relate the many innovation structures and research programs of a public university, so that successful marketing initiatives can be made viable, are not consolidated in literature. With that said, the study developed by Etzkowitz et al. (ETZKOWITZ et al., 1995), consolidated in the concept of a triple propeller, will be used as the conceptual basis of the study.

The study seeks to deepen the understanding of the case of the company Macofren, coming from a laboratory of the UnB. The techniques proposed in the case studies (YIN, 2009) will be used in this research. One of the authors of the article accompanied all the actions that generated the company Macofren. At a closer moment as responsible for the activities of technology protection and technology transfer at the UnB, at more distant moments by observing the development of the company that inhabited the innovation environment of the Technological Development Support Center (CDT/UnB), where patent activities also occur in UnB.

Documentary research is carried out in the documents of technical detail of the patent granted to the company, as well as in the contractual aspects and monitoring of the incubation process. In addition, the researchers had access to consultancies held as partnerships between the company and other laboratories of the UnB, with a more technological and managerial nature. The elements of documentary research sought to understand the context of the process of support given by the University to the company as a way of configuring it.

\section{Results}

The UnB is organized through institutes and departments that bring together undergraduate and postgraduate courses, as well as departments for the organization of teaching, research and extension in a transdisciplinary way, contributing to the development of academic life and society that surrounds it. Among them, the Institute of Chemistry is one of the most dynamic centers, developing many innovative technologies in the fields of basic and industrial Chemistry and high intensive technologies in Chemistry as a whole.
In Chemistry, innovations are gaining more importance for the society to improve life quality. An example is the prospective technology of the patent in question, which is the field of many alternative methods for simpler and cheaper technology to determine methanol and formaldehyde content in fuels.

Actually, the Laboratory of Materials and Fuels (LMC) located in Institute of Chemistry of the UnB solves problems presented by companies of the Oil and Gas sector. The laboratory in which the technology was developed had investments in the order of R $\$ 10$ million, both from sectoral funds of the Federal Government, development agencies such as CAPES, CNPq, Finep and FAPDF, as well as public institutions such as the Banco do Brasil Foundation and Embrapa, and with companies such as Rhodia and Copape.

\subsection{Development of technology}

This lab has developed many technologies able to improve the biofuel and biorefinery industries. Given the success of the developed technologies, the research group, involving masters and doctoral students, worked to develop and consolidate the technologies for the productive sector.

Specially, a master student created a colorimetric kit for the detection of methanol in ethanol fuel in the monitoring of the quality of fuels. It was his first motivation because the traditional analysis (chromatography analysis) is so expensive and it is longer than other fuel analysis. Based on the routine, a colorimetric kit for methanol detection in ethanol-containing fuels and ease of use in the field was developed and tested. The analysis can detect the presence of methanol in fuels when exceeding specification $(0.5 \% \mathrm{v} / \mathrm{v})$ in about $20 \mathrm{~min}$ and its simple instrumentation does not require a specialist. The kit method was successfully validated at gas stations located in the State of São Paulo and the Federal District. After that, the kit was applied for cosmetic and food products (MARTINS et al., 2015; SUAREZ et al., 2012).

The kit has five reagents in its composition. The first reagent is distilled water, necessary to dilute the ethanol sample. The second reagent is a diluted ethanol / methanol solution containing the amount of methanol, referring to the limit quantity stipulated by national legislation for comparison purposes. The third reagent is a $30 \mathrm{~g} . \mathrm{L}^{-1}$ potassium permanganate solution in phosphoric acid. To obtain this solution, $3 \mathrm{~g}$ of potassium permanganate are dissolved in water. After that, $15.5 \mathrm{~mL}$ of phosphoric acid is added, then completing with distilled water to $100 \mathrm{~mL}$. The fourth reagent is an oxalic acid solution of 50 g. $\mathrm{L}^{-1}$ in sulphuric acid. This solution is prepared by the slow addition of $50 \mathrm{~mL}$ of sulphuric acid in $50 \mathrm{~mL}$ of distilled water, with posterior addition of $5 \mathrm{~g}$ of oxalic acid to the mixture. The solution of oxalic acid is responsible for reducing the excess of permanganate, reducing it to $\mathrm{Mn}^{2+}$, which is soluble and 
colorless in aqueous solution, making the solution colorless and translucent. The last reagent in the kit is the Schiff Reagent, which is obtained by adding $0.75 \mathrm{~g}$ of p-rosaniline in $250 \mathrm{~mL}$ of distilled water, followed by the addition of $1.6 \mathrm{~g}$ of sodium metabisulphite and $6.7 \mathrm{~mL}$ of sulphuric acid solution of approximately 295 g. $\mathrm{mL}^{-1}$. The mixture is capped and put to rest for $12 \mathrm{~h}$ at approximately $20^{\circ} \mathrm{C}$. After resting, the solution is treated with activated carbon, to remove excess of dyes (MARTINS et al., 2017).

With the necessary reagents to carry out the analysis, the objective was to develop a practical way of using them, avoiding the handling and exposure of the reagents. The simplification of the use of the technique was also an aim, since the idea of the kit is that it is to be used by managers in gas stations or even attendants, that is, lay people about the technical knowledge of chemistry.

For this purpose the use of dispensers for the analysis reagents, which come with fixed volumes to carry out the analysis, has been conceived. Next, a prototype was developed to accommodate the dispensers, as well as other fundamental parts for the application of the analysis. In this panorama, the kit case was visualized and designed, which is suitable to accommodate the dispensers, as well as to allow the space for its handling between the other pieces, occupying the smallest possible space. The principle of the case is its compaction, which, when opened, can be compared to a mini-lab for the methanol detection technique. The base of the kit is the case, separated into several insertable compartments, which are intended to accommodate the other components necessary for the execution of the analysis in a practical and fast way, according to Figure 1.
Some community demands arose to evaluate the presence of formaldehyde in other products, such as beauty products, food and medicines. In a short period of time, the demands were met and one more master and one undergraduate student were involved in the improvement and adaptation of the technology for the new applications. The dissertation of the student in question studied the use of technology with adaptations to the productive process of dairy products in a large national company. The undergraduate student adapted the technology for an easy reading of the results for cleaning products and cosmetics. The demands were received by the CDT/UnB through the areas of technological services, called disk technology, and were referred to the teacher responsible for the LMC. At that moment, the opportunity to stimulate the students to set up a company was seen in order to meet the market in the face of the demand and the lack of the national market.

\subsection{Technology protection}

After that, the CDT/UnB was requested to work in writing the patent of the core technology. The technology protection was architected as an invention patent model respecting all the Brazilian legal requires. The patent in question describes the way of fast and low-cost methanol and formaldehyde content identification in some products, such as: fuels, food, pharmaceutical, cosmetic, milk and others. The IP of University of Brasilia (UnB), (21) BR 102012 012197-2 A2, named "Method of Schiff stabilization reactant in some vehicles, immobilized Schiff reactant in solid matrices, process of reactant impregnation, method of analytical determination of samples based on the use of the stable Schiff reactant, kit for determination

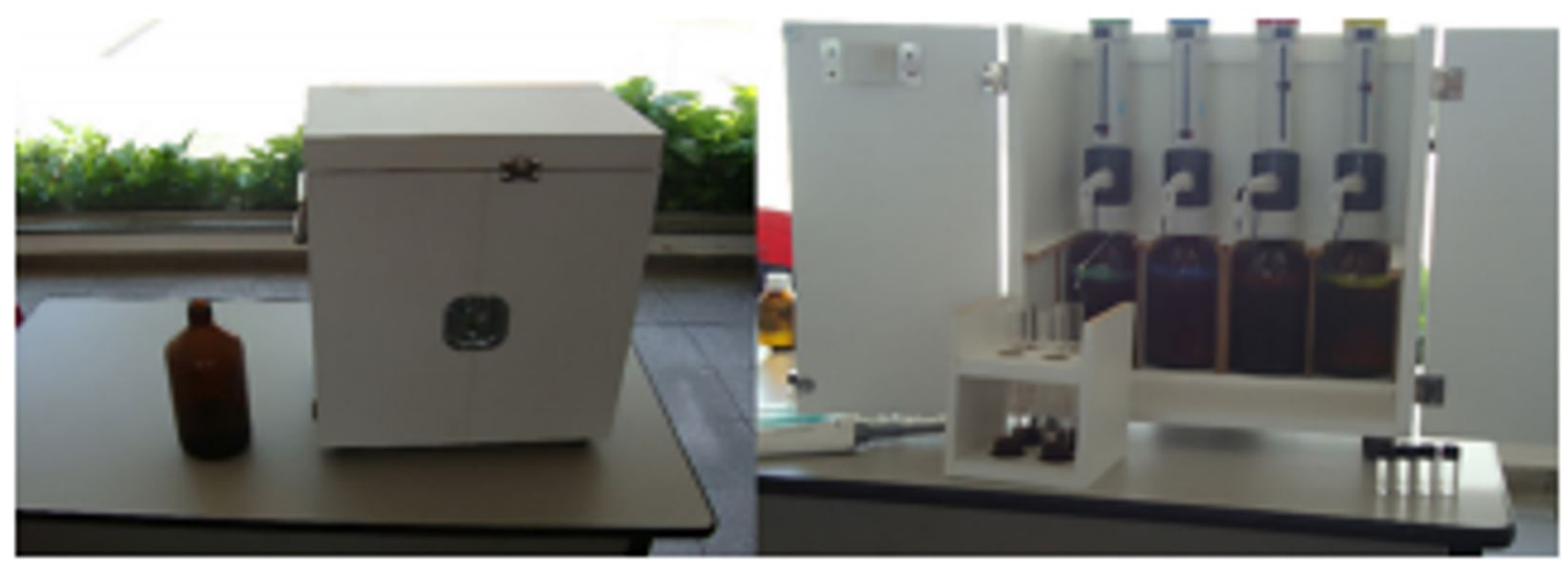

Figure 1. Images of the methanol analysis kit used in the field, where at the left is the image of the closed case, and at the right, the open case and some of its components (MARTINS et al., 2015). 
especially for methanol and formaldehyde in commercial products and its applications", was the result of the whole effort previous described (SUAREZ et al., 2012).

The level of readiness and maturity of the technology in question was evaluated through TRL (Technology Readiness Level) where it was characterized with TRL8 to TRL9 which indicates technology termination, with high interaction with incubators, technology parks, accelerators, etc.; traditionally called demonstration and then commercial. The protection of the technology was carried out fastly: ten months passed between the beginning of the process and the submission of the patent to INPI (National Institute of Industrial Property).

When submitting the technology for protection purposes, the research group's strategy, considering the chief researcher of the laboratory of fuels and its students involved in the technology, was already the establishment of a company to commercially exploit the products derived therefrom, as well as the incubation of the company in the $\mathrm{CDT} / \mathrm{UnB}$ as a way to enable such business development.

\subsection{Opening of startup and technology licensing}

In parallel with the technology protection process, the young people involved in the technical and scientific work related to fuel analysis founded MACOFREN - Chemical Technologies, an innovative startup, in order to license and commercialize the technology and to apply for a pre-incubation (in University of Brasilia) announcement with a company.

The company started its operation with two partners, both from the area of Chemistry. Just at the beginning, a Design student was incorporated into the team to support all activities, since the partners dominated all the technology, but also carried out the activities of marketing and sales of the kits, demonstrations, etc.

After 7 months under negotiation conditions, the Startup Macofren - Chemical Technology licensed the technology for 5 years with royalty of $10 \%$, since there was no upfront in signing the contract.

\subsection{Incubation in CDT}

Concurrently to the process of protection and technology licensing, the company submitted a business plan for approval in the pre-incubation program of $\mathrm{CDT} / \mathrm{UnB}$ incubator. Being approved, the Startup Macofren - Chemical Technology was conducted to the incubation program which has the objective to spread the entrepreneurs for undergraduate and post graduate students. For that, an incubation plan is structured as well as the offer of disciplines of entrepreneurship and innovation in its undergraduate courses to encourage the entrepreneurial spirit in the students and train entrepreneurs to market and sell their products. In addition, the company paid to the
UnB $1 \%$ of the company's revenues as a counterpart to the incubation process.

One of the company's first efforts was the structuring and refinement of its product lines, consisting of kits with specific application that were developed basing on the patent in order to make them easy to use and to enhance the commercialization of the technology (Figure 2).

The incubation process provided partnerships with laboratories of the university, such as: Laboratory of Analysis of Milk and Derivatives, Department of Agronomy and Veterinary Medicine, which presented three (3) course completion papers, related to validation and industrial use of the FormFix Reagent (Figure 2B and E), Safemilk (Figure 2A), Safemilk app (Figure 2C), and with the Laboratory of Materials and Fuels from which the technology was developed, where they developed the methanol kit (Figure 2C), also promoting 2 scientific initiation and 1 master's degree projects. The latter product has the advantage of portability and allows the identification of fuel adulteration.

In 2016, the company obtained access to the National Agency for Petroleum, Natural Gas and Biofuels (ANP), demonstrating its solution that, compared to the chromatographic analysis previously suggested by the Agency, offered a lower unit cost, easier realization, without the need of highly qualified technicians, and mainly, quick result (in a few minutes), while the chromatography demanded a week for delivery of the result. Still in 2016, the kit was validated by the ANP to be used in inspections at gas stations. With this certification, the company's sales increased exponentially, being the product with the greatest turnover. The company also has a product to identify the presence of formaldehyde and other maleficent aldehydes in cosmetics. In addition, a graduate student from the Communication course carried out, as an undergraduate

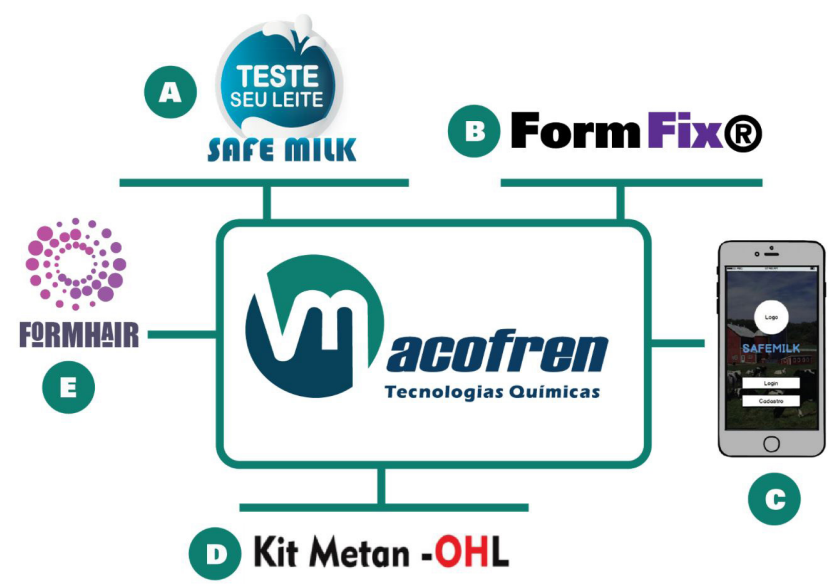

Figure 2. Products developed by the company from the licensed technology. 
thesis, the development of visual identities and folders for better marketing of products.

The involvement with the University allowed the Startup to get some financial support from the government. From the National Council for Research (CNPq) the company got fellowships for two researchers to aid in the developing of tests and improvement of the robustness of its products. From the Government Agency of Research and Projects (FINEP) the company got funding for payment of agents and equipments to develop its innovative projects, and those mentioned robustness tests. These fundings are opened for every company in Brazil, but the link to a University program improves the probability of acquiring them.

Macofren remained incubated for approximately 2 (two) years and a half, graduating earlier than expected due to the need of space and laboratory conditions to produce the kits, which were then demanded in high volume. The company earned more than $R \$ 1,000,000.00$ in 2 years of the incubator contract. Data illustrated in Figure 3 presents the company's revenue until last September when an effort to forecast demand in order to perform the capacity plan for a new factory was in place under a partnership with students and teachers of industrial engineering at UnB.

Currently, students in other undergraduate courses, such as design and production engineering, have been hired by the company to develop other business fronts such as marketing, manufacturing and visual identity. As shown in Figure 3, the fuel test product is exponential and is currently the company's priority market. The ciphers linked to the payment of royalties to the university demonstrate the viability of the University's technology protection and licensing activities for the public of the startups. Accordingly, in the first year of commercialization (2014-2015), royalties of R $\$ 970.00$ were attained, in the second year of commercialization (2015-2016) this value was of $\mathrm{R} \$ 2,700.00$ and in the third year of commercialization (2016-2017) the royalties should close around $\mathrm{R} \$ 100,000.00$. In addition, the rates of $1 \%$ on sales amounted to only about R $\$ 6,000.00$ during the incubation of the company.

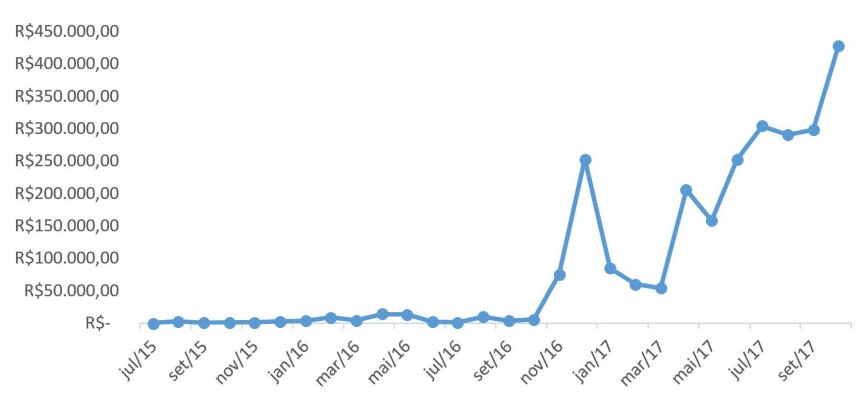

Figure 3. Macofren's revenues over the years of 2015-17.

\section{Final remarks and discussion}

This case is an example of innovative technology developed at the University of Brasilia and licensed for postgraduate students and entrepreneurs of the University of Brasilia who created the Startup Macrofren - Chemical Technology. Therefore, this case shows the Innovation Habitats from University of Brasilia.

The case demonstrates how a laboratory service program can be a means to identify a market opportunity. With the work of students of scientific initiation and masters, a robust technology was developed to solve a very common problem of the fuel business in Brazil. In this sense, it is observed that the work of more basic levels of research, if aimed at solving market situations, which often do not require knowledge in the state of the art, but only well-defined applications, can boost important results in the business environment.

The University in Brazil has as a fundamental element to implement the triple propeller, the Nuclei of Technological Innovation focusing on the protection and licensing of technologies. This structure was active in the case described in which the technology developed in the laboratory in only 18 months became a patent protected by the University. It still worked at the moment of the technology licensing of the Startup to the students involved in its development, building a viable licensing format for nascent companies.

In addition, the innovation environment created by the University's Innovation Habitat offered courses in entrepreneurship and the strengthening of relations with the Brazilian Support Service for Small and Medium Enterprises (SEBRAE), which enabled the group of students to take the necessary path to create their company startup. The company also found in the University environment the Incubation Program that offered physical structure, internet, telephony etc., as well as mentoring, events and business and technological opportunities provided by the University itself that allowed the company to develop new products in the various laboratories available to do so, in partnership with several teachers and researchers from various knowledge fields, using funds from research investment funds of the Federal Government, especially for the maintenance of researchers in the company.

Combined with the business environment, in which the prices of petroleum-based fuels have grown considerably, the prices of alternative fuels have also risen, thereby increasing the risk of fraud and thus the need for more supervision. This context created the opportunity for the company to be one of the first certified to carry out tests on the degree of formaldehyde of fuels sold in Brazil.

Nowadays, the company grows exponentially and encourages the regional innovation environment, either with the involvement of University students in its staff, or 
by the productive investment in the region and its expansion into new markets.

New researches can sum all the University investment in the Company, as well as investments done by $\mathrm{CNPq}$, FINEP and the Government policy in form of control of the quality of oil, and can also characterize better the way these politics are addressed by the company to grow as previously presented. The concept of entrepreneurial state can be used to build a more concise framework for understanding the whole pattern of Brazilian Government action in this kind of endeavor.

\section{References}

CHESBROUGH, H. W. Why companies should have open business models. MIT Sloan Management Review, v. 48, n. 2, p. 22-28, 2007.

CHRISTENSEN, C. M. et al. Innovation and the general manager. 2nd ed. California: Irwin/McGraw-Hill, 1999. p. $182-200$.

ETZKOWITZ, H. et al. The Triple Helix: university-industrygovernment relations: a laboratory for knowledge based economic development. EASST Review, v. 14, p. 14-19, 1995.

GUERRERO, M.; URBANO, D. The impact of Triple Helix agents on entrepreneurial innovations performance: An inside look at enterprises located in an emerging economy. Technological Forecasting and Social Change, v. 119, p. 294-309, 2017. http://dx.doi.org/10.1016/j. techfore.2016.06.015.

IVANOVA, I. A.; LEYDESDORFF, L. Rotational symmetry and the transformation of innovation systems in a Triple Helix of university-industry-government relations. Technological Forecasting and Social Change, v. 86, p. 143-156, 2014. http://dx.doi.org/10.1016/j.techfore.2013.08.022.

LEYDESDORFF, L. et al. Triple Helix indicators of knowledge-based innovation systems Introduction to the special issue. Research Policy, v. 35, p. 1441-1449, 2006.

LEYDESDORFF, L.; IVANOVA, I. "Open innovation" and "triple helix" models of innovation: can synergy in innovation systems be measured? Journal of Open Innovation: Technology, Market, and Complexity, v. 2, n.
1, p. 11-12, 2016. http://dx.doi.org/10.1186/s40852-0160039-7.

MARTINS, G. B. C. et al. Kit colorimétrico para detecção de metanol em etanol combustível para o monitoramento da qualidade de combustíveis. Quimica Nova, v. 38, p. 280-284, 2015.

MARTINS, G. B. C. et al. Papel indicador colorimétrico para detecção de formol em produtos lácteos e produtos de higiene pessoal. Quimica Nova, v. 40, p. 946-951, 2017.

MAZZUCATO, M. The entrepreneurial state. Soundings, v. 49, n. 49, p. 131-142, 2011. http://dx.doi. org/10.3898/136266211798411183.

NASSIF, V. M. J. et al. Entrepreneurs self-perception of planning skills: evidences from Brazilian entrepreneurs. Revista Ibero-Americana de Estratégia, v. 13, n. 4, p. 107-121, 2014. http://dx.doi.org/10.5585/riae.v13i4.2060.

RASMUSSEN, E.; BORCH, O. J. University capabilities in facilitating entrepreneurship: A longitudinal study of spinoff ventures at mid-range universities. Research Policy, v. 39 , n. 5 , p. $602-612,2010$. http://dx.doi.org/10.1016/j. respol.2010.02.002.

RASMUSSEN, E.; MOSEY, S.; WRIGHT, M. The influence of university departments on the evolution of entrepreneurial competencies in spin-off ventures. Research Policy, v. 43, n. 1, p. 92-106, 2014. http://dx.doi.org/10.1016/j. respol.2013.06.007.

SUAREZ, P. A. Z. et al. Method of schiff stabilization reactant in some vehicles, immobilized schiff reactant in solid matrices, process of reactant impregnation, method of analytical determination of samples based on the use of the stable schiff reactant, kit for determination specially for methanol and formadehyde in comercial products and its applications. BR n. PI 10.2012.0121972, 2012.

VAN GEENHUIZEN, M.; SOETANTO, D. P.. Academic spinoffs at different ages: a case study in search of key obstacles to growth. Technovation, v. 29, n. 10, p. 671-681, 2009. http://dx.doi.org/10.1016/j.technovation.2009.05.009.

YIN, R. K. Case study research: design and methods. 4th ed. London: Sage Publications, 2009. p. 124-182. 